\title{
Towards a structure-performance relationship for hydrogen storage in Ti-doped $\mathrm{NaAlH}_{4}$ nanoparticles $\dagger$
}

\author{
Cornelis P. Baldé, ${ }^{a}$ Olivier Leynaud, ${ }^{b c}$ Paul Barnes, ${ }^{b c}$ Elena Peláez-Jiménez, ${ }^{a}$ \\ Krijn P. de Jong ${ }^{a}$ and Johannes H. Bitter*a
}

Received 24th July 2010, Accepted 14th October 2010

DOI: $10.1039 / \mathbf{c 0 c c 0 2 7 8 7 a}$

Hydrogen storage properties of Ti-doped nanosized $(\sim 20 \mathbf{~ n m})$ $\mathrm{NaAlH}_{4}$ supported on carbon nanofibers were affected by the stage at which $\mathrm{Ti}$ was introduced. When Ti was deposited first followed by $\mathrm{NaAlH}_{4}$, sorption properties were superior to the case where $\mathrm{NaAlH}_{4}$ was deposited first followed by $\mathrm{NaAlH}_{4}$. This was the result of both a smaller $\mathrm{NaAlH}_{4}$ particle size and the more extensive catalytic action of $\mathrm{Ti}$ in the former material.

Sodium alanate has become a show-case for research on lightweight complex metal hydrides for hydrogen storage. ${ }^{1}$ Nevertheless, hydrogen release rates and absorption rates are often impeded in metal hydrides and need to be improved. ${ }^{2}$ Most effective in improving the performance of metal hydrides are reducing the particle size to the $\mathrm{nm}$ range (typically below $30 \mathrm{~nm})^{3-13}$ or adding one or more promoters/catalysts to bulk materials. ${ }^{14-25}$

The aim of the current research is to investigate the possible advantage of adding a Ti catalyst to $\mathrm{NaAlH}_{4}$ particles of $\sim 20 \mathrm{~nm}$ supported on carbon nanofibers (CNF). The order of $\mathrm{Ti}$ and alanate deposition, to achieve an optimal alanate-Ti interaction is discussed. The hydrogen storage characteristics of these materials is compared to undoped nano- $\mathrm{NaAlH}_{4}$ on $\mathrm{CNF}$ and ball milled $\mathrm{TiCl}_{3}-\mathrm{NaAlH}_{4}$ (alanate crystallite size 150-200 nm). Structure activity relationships will be established by relating information from Ti K-edge Extended X-ray Absorption Fine Structure (EXAFS) and in situ X-ray Diffraction (XRD) results with the hydrogen absorption and desorption characteristics of the samples.

The "Ti first" sample was prepared by first a pore volume impregnation with $10 \mathrm{~mol} \% \mathrm{Ti}(\mathrm{OBu})_{4}$ (compared to $\left.\mathrm{NaAlH}_{4}\right)$ in diethyl ether. After removal of the diethyl ether, $8 \mathrm{wt} \% \mathrm{NaAlH}_{4}$ was impregnated using THF followed by slow drying. The sample will be referred to as " $\mathrm{NaAlH}_{4}-\mathrm{Ti} / \mathrm{CNF}$ ". All sample handling was performed in an inert atmosphere either using Schlenk techniques or using a glove box. The "alanate first" sample of identical composition was prepared by reversing the impregnation order of $\mathrm{NaAlH}_{4}$ and $\mathrm{Ti}(\mathrm{OBu})_{4}$; however, after both steps the

\footnotetext{
${ }^{a}$ Inorganic Chemistry and Catalysis, Utrecht Univeristy,

Sorbonnelaan 16, 3096 TB Utrecht, The Netherlands

${ }^{b}$ School of Crystallography, Birkbeck College (University of London), Malet Street, London, WC1E $7 H X, U K$

${ }^{c}$ Department of Chemistry, Univ. College London, 20 Gordon Street, London, WC1H OAJ, UK

$\dagger$ Electronic supplementary information (ESI) available: Additional details: Figures S1 and S4, and Tables S1 and S2. See DOI: 10.1039/c0cc02787a
}

slow drying procedure was applied. This sample will be referred to as "Ti-NaAlH $4 / \mathrm{CNF}^{-}$". An undoped nano- $\mathrm{NaAlH}_{4}$ with a similar $\mathrm{NaAlH}_{4}$ loading of $8 \mathrm{wt} \%$ was prepared using the same procedure. This sample will be referred to as " $\mathrm{NaAlH}_{4} / \mathrm{CNF}$ " and had alanate particle sizes from $20-30 \mathrm{~nm} .{ }^{3}$ For comparison, a bulk sample was prepared by ball milling $\mathrm{TiCl}_{3}$ with purified $\mathrm{NaAlH}_{4}$ (Ti: $\mathrm{Al}=4.5 \mathrm{~mol} \%$ ) using a SPECS ball milling apparatus as described by Haiduc et al. ${ }^{26}$ This sample will be referred to as "ball milled $\mathrm{TiCl}_{3}-\mathrm{NaAlH}_{4}$ ". Further details can be found in the ESI. $\dagger$ Bulk sodium alanate only starts to desorb hydrogen around its melting point, i.e. $180{ }^{\circ} \mathrm{C}$. Fig. 1 displays the hydrogen desorption profiles for the (doped) nano-alanate samples. $\mathrm{NaAlH}_{4} / \mathrm{CNF}$ shows two desorption rate maxima one around $90{ }^{\circ} \mathrm{C}$ and one around $160{ }^{\circ} \mathrm{C}$. These two maxima have been attributed before ${ }^{3}$ to the broad range of particle sizes present in the sample. Small particles (not detected in XRD; $<10 \mathrm{~nm}$ ) desorb at the lower temperature while 20-30 nm particles desorb hydrogen at $150{ }^{\circ} \mathrm{C}$. ${ }^{3}$ When Ti was added only one maximum for desorption was observed in this temperature range i.e. at $132{ }^{\circ} \mathrm{C}$ for $\mathrm{Ti}-\mathrm{NaAlH}_{4} / \mathrm{CNF}$ and at $99{ }^{\circ} \mathrm{C}$ for $\mathrm{NaAlH}_{4}-\mathrm{Ti} / \mathrm{CNF}$ though the peaks are broad possibly resulting from some heterogeneity within the samples. Clearly the addition of $\mathrm{Ti}$ affects the desorption temperature. It has to be noted here that the starting material for $\mathrm{Ti}-\mathrm{NaAlH}_{4} / \mathrm{CNF}$ was $\mathrm{NaAlH}_{4} / \mathrm{CNF}$. When comparing the desorption characteristics of those two samples the low temperature shoulder present for $\mathrm{NaAlH}_{4}$ was not observed when "Ti" is present which might indicate that these smallest particles have reacted with the $\mathrm{Ti}(\mathrm{OBu})_{4}$ during doping.

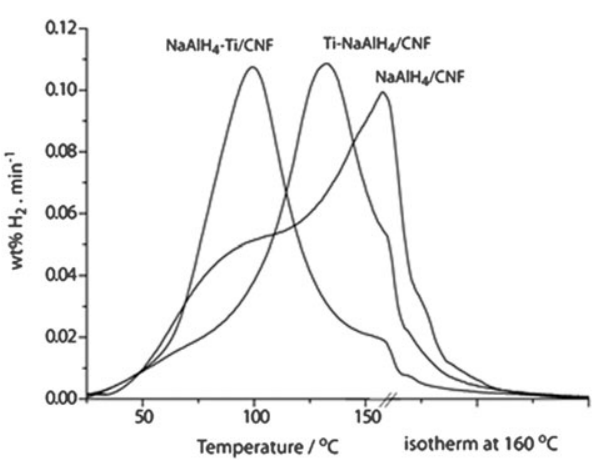

Fig. 1 Desorption profiles for various. $\left(2{ }^{\circ} \mathrm{C} \mathrm{min}^{-1}\right.$, normalized $\mathrm{NaAlH}_{4}$ loading ( $>90 \%$ of the theoretical amount of hydrogen was desorbed for each sample). 
Please note that also for reloading, in a Rubotherm high pressure magnetic suspension balance, ${ }^{27,28}$ the addition of $\mathrm{Ti}$ to nanosized $\mathrm{NaAlH}_{4}$ was beneficial (ESI, Fig. S1†). However, the storage capacity of the samples decreased with the number of absorption/desorption cycles (Table S1, ESI $\dagger$ ) indicating irreversible deactivation.

From Fig. 1 it is concluded that the order of Ti addition to nanosized $\mathrm{NaAlH}_{4}$ had a significant influence on the hydrogen desorption properties of the materials of which $\mathrm{NaAlH}_{4}-\mathrm{Ti} / \mathrm{CNF}$ showed the highest desorption rate maximum at the lowest temperature. To investigate the possible reason for that, the samples were characterized by XRD (synchrotron radiation, SRS Daresbury station 6.2) and EXAFS. XRD diffractograms of the prepared samples are shown and discussed in the ESI (Fig. S2). $\dagger$ We first focus here on the comparison between Ti-NaAlH $4 / C N F$ and $\mathrm{NaAlH}_{4} / \mathrm{CNF}$. The average $\mathrm{NaAlH}_{4}$ crystallite sizes of the samples were about $20 \mathrm{~nm}$. The peak intensities of the $\mathrm{NaAlH}_{4}$ diffraction lines for $\mathrm{Ti}-\mathrm{NaAlH}_{4} / \mathrm{CNF}$ and $\mathrm{NaAlH}_{4} / \mathrm{CNF}$ were also comparable, thus the content of $\sim 20 \mathrm{~nm} \mathrm{NaAlH}_{4}$ particles was similar. Therefore, it is concluded that the particle size distribution, for the XRD detectible part of the samples, did not differ significantly in $\mathrm{Ti}-\mathrm{NaAlH}_{4} / \mathrm{CNF}$ and $\mathrm{NaAlH}_{4} / \mathrm{CNF}$ after synthesis. This implies that the decrease in temperature at which the maximum desorption rate occurred $\left(T_{\max }\right)$ for $\mathrm{Ti}-\mathrm{NaAlH}_{4} / \mathrm{CNF}$, is the result of the catalytic action of the Ti-species present. In order to elucidate the structure of the Ti-nanoparticles in $\mathrm{Ti}-\mathrm{NaAlH}_{4} / \mathrm{CNF}$, their local structure was investigated with EXAFS prior to hydrogen desorption. EXAFS fit parameters (Table $\mathrm{S} 2$, ESI $\dagger$ ) reveal that Ti is surrounded by $\mathrm{O}$, $\mathrm{C}$ and $\mathrm{Ti}$ atoms. The absence of $\mathrm{Na}$ or $\mathrm{Al}$ atoms in the local structure indicates that Ti did not interact with the $\mathrm{NaAlH}_{4}$ to a level detectable by EXAFS (10 at\%). Since the local structure comprised the same atoms as the original Ti-precursor $\left(\mathrm{Ti}(\mathrm{OBu})_{4}\right)$, it was concluded that the majority of "Ti" was present as nanoparticles of $\mathrm{Ti}(\mathrm{OBu})_{4}$, or a decomposition product thereof, in the as-prepared $\mathrm{Ti}-\mathrm{NaAlH}_{4} / \mathrm{CNF}$.

Apparently, after synthesis the $\mathrm{Ti}(\mathrm{OBu})_{4}$ had not fully reacted with the alanate in $\mathrm{Ti}-\mathrm{NaAlH}_{4} / \mathrm{CNF}$. This incomplete reaction of the catalyst-precursor with the $\mathrm{NaAlH}_{4}$ has been reported previously for $\mathrm{NaAlH}_{4}$ ball-milled with $\mathrm{TiF}_{3}$ (micro-meter sized) ${ }^{29}$ and $\mathrm{Ti}(\mathrm{OBu})_{4}$ ball-milled with $\mathrm{NaAlH}_{4}{ }^{30}$ For $\mathrm{Ti}(\mathrm{OBu})_{4}$ ball milled with $\mathrm{NaAlH}_{4}$, it has been concluded from an in situ EXAFS study ${ }^{30}$ that the Ti species were reduced to the catalytically active $\mathrm{TiAl}_{x}$ phase during hydrogen extraction in the first desorption step. In accordance, we assume that the nanoparticles of $\mathrm{Ti}(\mathrm{OBu})_{4}$, or a decomposition product thereof, in the as-prepared $\mathrm{Ti}-\mathrm{NaAlH}_{4} / \mathrm{CNF}$ will react with the $\mathrm{TiAl}_{x}$ catalyst in $\mathrm{Ti}-\mathrm{NaAlH}_{4} / \mathrm{CNF}$ during the first desorption step. Therefore, although the Ti-alanate interaction was limited, still catalytic effects on desorption are apparent (Fig. 1).

Hereafter, we focus on the properties of the sample that showed the lowest $T_{\max }$ in the TPD profile $\left(\mathrm{NaAlH}_{4}-\mathrm{Ti} / \mathrm{CNF}\right.$ in Fig. 1). The crystallite size of the alanate was also in this sample $\sim 20 \mathrm{~nm}$. However, the intensity of the alanate diffraction was considerably reduced for this sample indicating that a larger fraction of $\mathrm{NaAlH}_{4}$ is amorphous or nanocrystalline (Fig. S2, ESI $\dagger$ ). Thus the average size and/or crystallinity of the $\mathrm{NaAlH}_{4}$ has been decreased in $\mathrm{NaAlH}_{4}-\mathrm{Ti} / \mathrm{CNF}$ compared to $\mathrm{NaAlH}_{4} / \mathrm{CNF}$ during the preparation.
Literature shows that the reduction of particle size of metal hydrides can significantly increase $\mathrm{H}_{2}$ desorption rates at lower temperatures. ${ }^{3-13}$ Thus, the particle size reduction of the $\mathrm{NaAlH}_{4}$, induced by the presence of $\mathrm{Ti}$, in $\mathrm{NaAlH}_{4}-\mathrm{Ti} / \mathrm{CNF}$ explained, at least partially, the lowest $T_{\max }$ in the TPD profile of Fig. 1. However, this might not be the sole explanation of the observed kinetic improvements, as the Ti species can be active as a catalyst as well.

Whether this is the case was investigated by an in situ XRD study. The evolution of crystalline alanate phases during hydrogen desorption were evaluated in the temperature range from room temperature to $200{ }^{\circ} \mathrm{C}$ for $\mathrm{NaAlH}_{4} / \mathrm{CNF}$ and $\mathrm{NaAlH}_{4}-\mathrm{Ti} / \mathrm{CNF}$. The integrated areas of the broadened $\mathrm{NaAlH}_{4}\left(2 \theta=26.85^{\circ}\right)$, $\mathrm{Na}_{3} \mathrm{AlH}_{6}\left(2 \theta=31.64^{\circ}\right)$, and $\mathrm{Al}\left(2 \theta=34.79^{\circ}\right)$ diffraction lines are shown in Fig. 2 as a function of temperature. We realize that amorphous phases or nanocrystalline phases cannot be observed by XRD. It is, however, tentatively assumed that the conclusions drawn from XRD are also relevant for the non crystalline fractions of the samples in view of the broad but single-peak desorptions of $\mathrm{H}_{2}$ in the TPD experiments (see Fig. 1). For $\mathrm{NaAlH}_{4}-\mathrm{Ti} / \mathrm{CNF}$, the $\mathrm{NaAlH}_{4}$ line intensity decreased with increasing temperature starting at $20{ }^{\circ} \mathrm{C}$ and became zero at $115^{\circ} \mathrm{C}$. The $\mathrm{Al}$ line grew steadily from $40^{\circ} \mathrm{C}$ and stabilized when the temperature reached $130^{\circ} \mathrm{C}$. Weak $\mathrm{Na}_{3} \mathrm{AlH}_{6}$ diffraction lines were detected at temperatures between 105 and $150{ }^{\circ} \mathrm{C}$.

For $\mathrm{NaAlH}_{4} / \mathrm{CNF}$, the $\mathrm{NaAlH}_{4}$ diffraction started to decrease from $20{ }^{\circ} \mathrm{C}$ and became zero at $150{ }^{\circ} \mathrm{C}$. In the same low temperature range, the $\mathrm{Al}$ diffraction intensity was constant. However above $150{ }^{\circ} \mathrm{C}$, the $\mathrm{Al}$ diffraction rapidly increased and stabilized at $190{ }^{\circ} \mathrm{C}$. Weak $\mathrm{Na}_{3} \mathrm{AlH}_{6}$ diffractions were only observed at high temperature $\left(150\right.$ to $\left.180{ }^{\circ} \mathrm{C}\right)$ i.e., after all $\mathrm{NaAlH}_{4}$ had decomposed.

Since the FWHM of the $\mathrm{NaAlH}_{4}$ diffraction was similar in $\mathrm{NaAlH}_{4} / \mathrm{CNF}$ and $\mathrm{NaAlH}_{4}-\mathrm{Ti} / \mathrm{CNF}$, i.e., the crystalline part of the $\mathrm{NaAlH}_{4}$ had a similar crystallite size (Fig. S2, ESI $\dagger$ ), thus the role of the "Ti" on the $\mathrm{NaAlH}_{4}$ decomposition could therefore be independently investigated by monitoring the evolution of the diffraction patterns. It was observed that the $\mathrm{NaAlH}_{4}$ diffraction peaks reached zero intensity at a considerably lower temperature when "Ti" was present $\left(\mathrm{NaAlH}_{4}-\mathrm{Ti} /\right.$ $\mathrm{CNF}$ ) than when "Ti" was absent $\left(\mathrm{NaAlH}_{4} / \mathrm{CNF}\right)$. Apparently, "Ti" accelerated decomposition of the $\mathrm{NaAlH}_{4}$ particles in $\mathrm{NaAlH}_{4}-\mathrm{Ti} / \mathrm{CNF}$, thus acting as a catalyst.

From Fig. 2 it also becomes clear that crystalline $\mathrm{Na}_{3} \mathrm{AlH}_{6}$ did not show up as long as the nano-sized $\mathrm{NaAlH}_{4}$ was present. In contrast, for non supported $\mathrm{Ti}(\mathrm{OBu})_{4}$ catalyzed $\mathrm{NaAlH}_{4}$, an in situ diffraction study by Gross et al. indicated that $\mathrm{Na}_{3} \mathrm{AlH}_{6}$
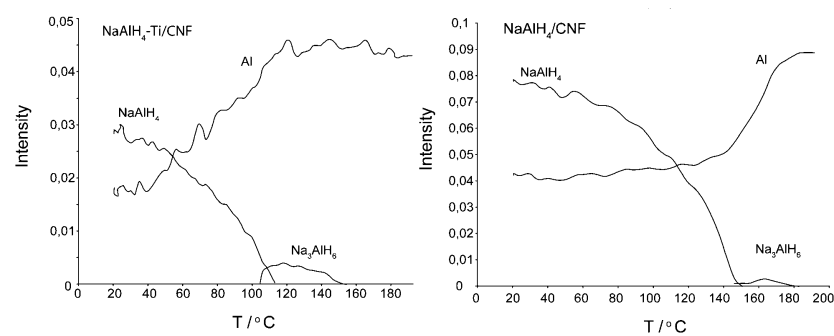

Fig. 2 Integrated areas of $\mathrm{NaAlH}_{4}\left(2 \theta=26.85^{\circ}\right), \mathrm{Na}_{3} \mathrm{AlH}_{6}$ $\left(2 \theta=31.64^{\circ}\right)$ and $\mathrm{Al}\left(\left(2 \theta=34.79^{\circ}\right)\right.$ diffractions during the in situ desorption $\left(5^{\circ} \mathrm{C} \mathrm{min}^{-1}\right.$, normalized to $\mathrm{CNF}$ peak). 
crystallized in co-presence of $\mathrm{NaAlH}_{4}{ }^{31}$ The simultaneous presence of $\mathrm{Na}_{3} \mathrm{AlH}_{6}$ and $\mathrm{NaAlH}_{4}$ during decomposition was also reported in an in situ XRD study of $\mathrm{TiCl}_{3}$-catalyzed bulk $\mathrm{NaAlH}_{4}{ }^{32}$ Thus, the decomposition mechanism of nano$\mathrm{NaAlH}_{4}$ differs noticeably from that of bulk-NaAlH . We hypothesize that nano- $\mathrm{NaAlH}_{4}$ decomposed directly to $\mathrm{H}_{2}$, $\mathrm{NaH}$ and $\mathrm{Al}$, thus largely bypassing the formation of crystalline $\mathrm{Na}_{3} \mathrm{AlH}_{6}$. Thermodynamically this is feasible (Fig. S3, ESI $\dagger$ ), also for bulk materials. The thermodynamic properties of Ti-doped nano alanate particles could be different than those for bulk materials as shown for undoped nanosized systems. ${ }^{9,14,33}$

The structural properties of the "Ti" species in $\mathrm{NaAlH}_{4}-\mathrm{Ti} /$ $\mathrm{CNF}$ as inferred from EXAFS indicated that $\mathrm{Ti}(\mathrm{OBu})_{4}$ reacts with $\mathrm{NaAlH}_{4}$ during the synthesis (see ESI $\dagger$ ). Since our samples have a total Ti-Al coordination number of 4.5 and a Ti-Ti coordination number of 0.7 the total $\mathrm{Ti}$ : Al ratio in our particles is $\sim 1: 6.4$. Thus the $\mathrm{TiAl}_{x}$ species have an average stoichiometry of $\mathrm{TiAl}_{6.4}$.

In the previous part, the structure of the Ti catalyst and its ability to decrease the particle size of the $\mathrm{NaAlH}_{4}$ in $\mathrm{NaAlH}_{4}-\mathrm{Ti}$ / $\mathrm{CNF}$ has been discussed. Now, we will elaborate on an explanation of how the "Ti" addition dispersed the $\mathrm{NaAlH}_{4}$ during its preparation. The first step in the preparation was the impregnation of liquid $\mathrm{Ti}(\mathrm{OBu})_{4}$ dissolved diethylether to the CNF. Subsequent drying deposited the liquid $\mathrm{Ti}(\mathrm{OBu})_{4}$ on the fibers. In a second impregnation, $\mathrm{NaAlH}_{4}$ dissolved in $\mathrm{THF}$ was added. $\mathrm{Ti}(\mathrm{OBu})_{4}$ is expected to dissolve in THF, thus could react with $\mathrm{NaAlH}_{4}$ forming a homogenously-dispersed $\mathrm{TiAl}_{x}$ species. This species is insoluble and precipitated on the CNF forming finely dispersed anchoring sites on the CNF. When the impregnated material was dried, the $\mathrm{NaAlH}_{4}$ deposited on the finely dispersed anchoring sites, which increased the dispersion of $\mathrm{NaAlH}_{4}$ during the preparation. Thus, the enhanced desorption rates at low temperature can be explained by two phenomena (a) the formation of a well mixed $\mathrm{Ti}-\mathrm{Al}$ catalyst and (b) the formation of a fraction of smaller $(<20 \mathrm{~nm})$ alanate particles.

In conclusion, $\mathrm{Ti}(\mathrm{OBu})_{4}$-modified $\mathrm{NaAlH}_{4}$ nanoparticles have been synthesized on carbon nanofibers (CNF) by impregnation and drying techniques. In the cases where the $\mathrm{NaAlH}_{4}$ was impregnated first and $\mathrm{Ti}(\mathrm{OBu})_{4}$ second, the particle size of the $\mathrm{NaAlH}_{4}$ did not change compared to a non-doped nano$\mathrm{NaAlH}_{4}$. The temperature at maximum desorption rate decreased from above $160{ }^{\circ} \mathrm{C}$ to $132{ }^{\circ} \mathrm{C}$ and is ascribed to the catalytic role of the $\mathrm{Ti}$ in that sample. Samples prepared by impregnating the $\mathrm{Ti}(\mathrm{OBu})_{4}$ first, and $\mathrm{NaAlH}_{4}$ second showed an $\mathrm{H}_{2}$ desorption maximum at $99^{\circ} \mathrm{C}$ in $\mathrm{Ar}$ and absorbed hydrogen from 10 bar $\mathrm{H}_{2}$ pressure at $115^{\circ} \mathrm{C}$ after hydrogen extraction. The outstanding hydrogen sorption properties were ascribed to two roles of the "Ti". First, the $\mathrm{NaAlH}_{4}$ particle size in $\mathrm{NaAlH}_{4}-\mathrm{Ti} /$ CNF was smaller $(<20 \mathrm{~nm})$ than in all other samples as a result of Ti nuclei facilitating alanate dispersion. Secondly, a highly dispersed " $\mathrm{TiAl}_{6.4}$ " phase was formed by the reaction between Ti-precursor and $\mathrm{NaAlH}_{4}$ which acted as an anchoring point thus restricting growth of $\mathrm{Al}$ crystallites during the desorption of $\mathrm{NaAlH}_{4}$. The Ti-doped nanoalanate decomposed without the formation of crystalline $\mathrm{Na}_{3} \mathrm{AlH}_{6}$ most likely as result of the modified thermodynamics of these small particles.

Financial support by NWO/ACTS systainable hydrogen, Hasylab Hamburg (station E4) and SRS Daresbury (station 6.2) are gratefully acknowledged.

\section{Notes and references}

1 L. Schlapbach and A. Züttel, Nature, 2001, 414, 353.

2 S. Orimo, Y. Nakamori, J. R. Eliseo, A. Züttel and C. M. Jensen, Chem. Rev., 2007, 107(10), 4111.

3 C. P. Balde, B. P. C. Hereijgers, J. H. Bitter and K. P. de Jong, J. Am. Chem. Soc., 2008, 130, 6761.

4 A. Gutowska, L. Li, Y. Shin, C. M. Wang, X. S. Li, J. C. Linehan, R. S. Smith, B. D. Kay, B. Schmid, W. Shaw, M. Gutowski and T. Autrey, Angew. Chem., Int. Ed., 2005, 44, 3578.

5 A. Feaver, S. Sepehri, P. Shamberger, A. Stowe, T. Autrey and G. Cao, J. Phys. Chem. B, 2007, 111(26), 7469-7472.

6 P. E. de Jongh, R. W. P. Wagemans, T. M. Eggenhuisen, B. S. Dauviller, P. B. Radstake, J. D. Meeldijk, J. W. Geus and K. P. de Jong, Chem. Mater., 2007, 19(24), 6052.

7 J. J. Vajo and G. L. Olson, Scr. Mater., 2007, 56(10), 829.

8 B. Bogdanovic and M. Schwickardi, J. Alloys Compd., 1997, 253-254, 1.

9 J. Gao, P. Adelhelm, M. H. W. Verkuijlen, C. Rongeat, M. Herrich, P. J. M. van Bentum, O. Gutfleisch, A. P. M. Kentgens, K. P. de Jong and P. E. de Jongh, J. Phys. Chem. C, 2010, 114.

10 P. Adelhelm, J. Gao, M. H. W. Verkuijlen, C. Rongeat, M. Herrich, P. J. M. M. van Bentum, O. Gutfleisch, A. P. M. Kentgens, K. P. de Jong and P. E. de Jongh, Chem. Mater., 2010, 22, 2233.

11 M. H. W. Verkuijlen, J. Gao, P. Adelhelm, P. J. M. van Bentum, P. E. de Jongh and A. P. M. Kentgens, J. Phys. Chem. C, 2010, 114, 4683.

12 R. K. Bhakta, J. L. Herberg, B. Jacobs, A. Highley, R. Behrens Jr, N. W. Ockwig, J. A. Greathouse and M. D. Allendorf, J. Am. Chem. Soc., 2009, 131, 13198.

13 H. Wu, ChemPhysChem, 2008, 9, 2157.

14 W. Lohstroh, A. Roth, H. Hahn and M. Fichtner, ChemPhysChem, 2010, 11, 789; A. Züttel, P. Wenger, S. Rentsch, P. Sudan, P. Mauron and C. Emmenegger, J. Power Sources, 2003, $118,1$.

15 X. Yao, C. Wu, A. Du, J. Zou, Z. Zhu, P. Wang, H. Cheng, S. Smith and F. Lu, J. Am. Chem. Soc., 2007, 129, 15650.

16 B. Bogdanovic, M. Felderhoff, A. Pommerin, F. Schüth and N. Spielkamp, Adv. Mater., 2006, 18, 1198.

17 M. Felderhoff, C. Weidenthaler, R. von Helmolt and U. Eberle, Phys. Chem. Chem. Phys., 2007, 9, 2643.

18 B. Sakintuna, F. Lamari-Darkrim and M. Hirscher, Int. J. Hydrogen Energy, 2007, 32, 1121.

19 J. Wang, A. D. Ebner, T. Prozorov, R. Zidan and J. A. Ritter, J. Alloys Compd., 2005, 395, 252.

20 S. Zheng, F. Fang, G. Zhou, G. Chen, M. Ouyang, M. Zhu and D. Sun, Chem. Mater., 2008, $20,3954$.

21 A. Marashdeh, R. A. Olsen, O. M. Løvvik and G.-J. Kroes, J. Phys. Chem. C, 2008, 112, 15759.

22 K. Bai, P. Shan, E. Yeo and Ping Wu, Chem. Mater., 2008, 20, 7539.

23 G. Krishna, P. Dathar and D. S. Mainardi, J. Phys. Chem. C, 2010, 114, 8026

24 J. W. Kim, J.-H. Shim, S. C. Kim, A. Remhof, A. Borgschulte, O. Friedrichs, R. Gremaud, F. Pendolino, A. Züttel, Y. W. Cho and K. H. Oh, J. Power Sources, 2009, 192, 582.

25 Y. Song, J. H. Dai, C. G. Li and R. Yang, J. Phys. Chem. C, 2009 , 113, 10215.

26 A. G. Haiduc, H. A. Stil, M. A. Schwarz, P. Paulus and J. J. C. Geerlings, J. Alloys Compd., 2005, 393(1-2), 252-263.

27 F. Dreisbach, R. Seif and H. W. Lösch, J. Therm. Anal. Calorim., 2003, 71, 73 .

28 H. W. Lösch, R. Kleinrahm and W. Wagner, Neue Magnetschwebewaagen für gravimertrische Messungen in der Verfahrentechnik, VDI-Verslag, Düsseldorf, 1994.

29 F. Fang, J. Zhang, J. Zhu, G. Chen, D. Sun, B. He, Z. Wei and S. Wei, J. Phys. Chem. C, 2007, 111, 3476.

30 C. P. Baldé, H. A. Stil, A. M. J. van der Eerden, K. P. de Jong and J. H. Bitter, J. Phys. Chem. C, 2007, 111, 2797.

31 K. J. Gross, S. Guthrie, S. Takara and G. Thomas, J. Alloys Compd., 2000, 297, 270.

32 K. J. Gross, G. Sandrock and G. J. Thomas, J. Alloys Compd., 2002, 330-332, 691

33 R. D. Stephens, A. F. Gross, S. L. van Atta, J. J. Vajo and F. E. Pinkerton, Nanotechnology, 2009, 20, 204018. 